九州大学学術情報リポジトリ

Kyushu University Institutional Repository

\title{
Evaluation of biological activities of extracts from the fruiting body of Pleurotus citrinopileatus for skin cosmetics
}

Meng, Tian-Xiao

Department of Agro-environmental Sciences, Faculty of Agriculture, Kyushu University

Furuta, Shoko

Department of Agro-environmental Sciences, Faculty of Agriculture, Kyushu University

Fukamizu, Sayaka

Department of Nutrition and Health Science, Faculty of Human Environmental Science, Fukuoka Women's University

Yamamoto, Ryoko

Department of Nutrition and Health Science, Faculty of Human Environmental Science, Fukuoka Women's University

他

http://hdl. handle. net/2324/25649

出版情報：Journal of Wood Science. 57 (5), pp.452-458, 2011-10-01. Springer Japan バージョン：

権利関係: (C) The Japan Wood Research Society 2011 


\section{Evaluation of biological activities of extracts from}

\section{the fruiting body of Pleurotus citrinopileatus for skin cosmetics}

Tian-Xiao Meng $\cdot$ Shoko Furuta $\cdot$ Sayaka Fukamizu $\cdot$ Ryoko Yamamoto $\cdot$ Hiroya Ishikawa

Enos Tangke Arung $\cdot$ Kuniyoshi Shimizu $\cdot$ Shoji Ohga $\cdot$ Ryuichiro Kondo

Corresponding author:

Dr. Kuniyoshi Shimizu

Address: 6-10-1 Hakozaki, Higashi-ku, Fukuoka, Japan, 812-8581

E-mail: shimizu@agr.kyushu-u.ac.jp

Phone/Fax: +81-92-642-3002 


\begin{abstract}
Pleurotus citrinopileatus Singer has recently become a popular delicacy in East Asian countries. We prepared a methanol extract, solubles from the methanol extract, and a hot water extract of the fruiting bodies of $P$. citrinopileatus. Additionally, their biological activities, including melanin biosynthesis inhibition, tyrosinase inhibition, antioxidant [1,1-diphenyl-2-picrylhydrazyl (DPPH) radical scavenging, oxygen radical absorbance capacity (ORAC) and superoxide dismutase (SOD)-like activity], and antibacterial and antihyaluronidase activities were evaluated. We found that the $n$-hexane, diethyl ether and ethyl acetate solubles showed melanin biosynthesis inhibition in B16 melanoma cells, as well as antioxidant (ORAC) and antibacterial activities. However, the $n$-butanol, aqueous solubles, and methanol and hot water extracts exhibited antioxidant (DPPH radical scavenging, SOD-like activity) and antihyaluronidase activities. These results indicate that the fruiting bodies of $P$. citrinopileatus have the potential to be used as an ingredient in skin cosmetics.
\end{abstract}

\title{
Key words
}

Pleurotus citrinopileatus; melanin inhibition; antioxidant; antibacterial; antihyaluronidase 


\section{Introduction}

Mushrooms are a nutritionally functional food and a source of physiologically beneficial medicines. The Pleurotus citrinopileatus is an edible mushroom (Synonymy: $P$. cornucopiae, P. cornucopiae var. citrinopileatus) belonging to the genus Pleurotus, Pleurotaceae. The name of this mushroom in English is golden oyster mushroom, tamogitake in Japanese, yuhuangmo in Chinese, goldenseed in Korean, and weishenga limonaya in Russian. It grows on fallen trees and stumps of broad-leaf tree species such as Ulmus sp., Quercus serrata, Accer palmatus and Fraxinus mandshurica.

A half dozen recent studies have focused on the cultivation of $P$. citrinopileatus with numerous multifunctional biological activities, for example antigenotoxicity ${ }^{1}$, angiotensin-converting enzyme (ACE) inhibition activity ${ }^{2}$, antihyperlipidemic activity ${ }^{3}$, antiatopic dermatitis activity ${ }^{4}$, antioxidant activities $^{5}$, anticancer activity ${ }^{5}$, and HIV-1 reverse transcriptase inhibitory activity. ${ }^{6}$ There are a limited number of previous studies on the chemical composition, and there have been few reports on lectin, peptide and protein identified from water extracts of $P$. citrinopileatus. ${ }^{2,7}$ The purpose of the present study was to evaluate some of the biological activities, such as the melanin inhibition, tyrosinase inhibition, antioxidant, antibacterial, and antihyaluronidase activities of a methanol extract and hot water extract of $P$. citrinopileatus and crude fractions prepared from the methanol extract in order to analyze the potential of $P$. citrinopileatus for use in skin cosmetics.

\section{Materials and methods}

\section{Mushroom materials}

Fresh fruiting bodies of $P$. citrinopileatus were obtained from Tamogitake Pharmaceutics Co. Ltd (Nagano, Japan). The fruiting bodies were cleaned to remove any residual and then freeze-dried. The milled freeze-dried P. citrinopileatus (10.0 g each) were extracted with methanol $(2 \times 100 \mathrm{ml})$ at room temperature with a shaker at $150 \mathrm{rpm}$ over $48 \mathrm{~h}$ then filtered. The methanol extract was concentrated by a rotary evaporator. The freeze-dried $P$. citrinopileatus $(10.0 \mathrm{~g})$ was treated with $2,000 \mathrm{ml}$ of distilled water and boiled $\left(100^{\circ} \mathrm{C}\right)$ for $1 \mathrm{~h}$, and the hot water extract was then centrifuged at 4,500 rpm for $20 \mathrm{~min}$, and the supernatant lyophilized. The yield of the methanol and hot water extracts were $1.0 \mathrm{~g}(10.0$ $\%$ ) and $1.2 \mathrm{~g}(12.0 \%)$, respectively.

The methanol extract $(1.0 \mathrm{~g})$ was successively partitioned with a series of organic 
solvents: $n$-hexane, diethyl ether, ethyl acetate and $n$-butanol. Each soluble was concentrated by a rotary evaporator and the resultant residue was put in water to form a suspension, and then freeze-dried. The recovery rate of each soluble was $n$-hexane (51.0 $\mathrm{mg}, 5.1 \%$ ), diethyl ether (43.0 mg, $4.3 \%$ ), ethyl acetate (59.0 mg, $5.9 \%$ ), $n$-butanol (209.0 mg, $20.9 \%$ ), and aqueous (563.0 mg, $56.3 \%$ ) solubles, respectively.

\section{Inhibitory effect on melanogenesis using cultured B16 melanoma cell}

Determination of melanin content

This assay was performed as previously described by Arung et al. ${ }^{8}$ The melanin content (MC) of cells after treatment was determined as follows. After removing the medium and washing the cells, the cell pellet was dissolved in $1.0 \mathrm{ml}$ of $1 \mathrm{~N} \mathrm{NaOH}$. The crude cell extracts were assayed using a micro plate reader (Bio-Tek, USA) at $405 \mathrm{~nm}$ to determine melanin content. The results from the samples were analyzed as a percent of the control culture. Arbutin was used as a positive control.

Cell viability

Cell viability $(\mathrm{CV})$ was determined by use of the microculture tetrazolium technique (MTT). ${ }^{8}$ Culture was initiated and after incubation, $50 \mu \mathrm{l}$ of MTT bromide in PBS (5 $\mathrm{mg} / \mathrm{ml}$ ) was added to each well. The plates were incubated for $4 \mathrm{~h}$. After removing the medium, formazan crystals were dissolved in $1.0 \mathrm{ml}$ of $0.04 \mathrm{~N} \mathrm{HCl}$, and the absorbance was measured at $570 \mathrm{~nm}$ relative to $630 \mathrm{~nm}$.

\section{Tyrosinase assay}

Although tyrosinase catalyzes a reaction between two substrates, a phenolic compound and oxygen, the assay was carried out in an air-saturated solution. Kojic acid ${ }^{9}$ was used as a positive control. The assay was performed as previously described. ${ }^{8}$ The absorbance at $475 \mathrm{~nm}$ was measured using a V530 spectrophotometer (Jasco, Japan) at 3 min for L-DOPA (Osaka, Japan) and 10 min for L-tyrosine (Osaka, Japan), respectively.

\section{Antioxidant assay}

Oxygen radical absorbance capacity (ORAC) assay 
The ORAC assay was performed as described previously by Prior et al. ${ }^{10}$ Data are expressed as milligram of Trolox equivalents (TE) per milligram of sample (mg TE/mg).

\section{1, 1-diphenyl-2-picrylhydrazyl (DPPH) radical scavenging assay}

This assay was performed as described previously by Shimamura et al. ${ }^{11}$, with minor modifications. The sample was first dissolved in ethanol or dimethylsulfoxide (DMSO, Osaka, Japan). The reaction mixture contained $1000 \mu 1$ of $0.2 \mathrm{mM}$ DPPH (Tokyo, Japan) in ethanol, $800 \mu \mathrm{l}$ of $0.1 \mathrm{M}$ Tris- $\mathrm{HCl}$ buffer ( $\mathrm{pH} 7.4$ ), and $200 \mu \mathrm{l}$ of sample solution in ethanol or DMSO. After the reaction was carried out at room temperature for 30 minutes, the free radical scavenging activity of the sample was quantified by the decolorization of DPPH at $517 \mathrm{~nm}$.

SOD-like activity

SOD-like activity was evaluated by using the SOD assay kit-WST (Dojindo Molecular Technologies, Inc., Kumamoto, Japan) according to the method described in previous studies. ${ }^{12}$ The sample was dissolved in Milli-Q water or ethanol and added to the WST working solutions (200 $\mu \mathrm{l})$ containing 2-(4-iodophenyl)-3-(4-nitrophenyl)-5-(2, 4-disulfophenyl)-2- $H$-tetrazolium in $50 \mathrm{mM}$ carbonate buffer ( $\mathrm{pH}$ 10.2). The enzyme working solution $(20 \mu \mathrm{l})$ containing xanthine oxidase in the same buffer was added and then incubated for $10 \mathrm{~min}$. The absorbance of each sample was measured at $450 \mathrm{~nm}$ in a Tecan Spectra microplate reader (Tecan Japan Co., Ltd., Kanagawa, Japan). One unit of SOD-like activity was defined as the amount of the extract in $20 \mu 1$ of sample solution that inhibits the reduction reaction of WST-1 with superoxide anion by $50 \%$. The SOD-like activity $(\mathrm{U} / \mathrm{mg})$ of each extract was calculated by using the $50 \%$ inhibition value $\left(\mathrm{IC}_{50}\right)$ of the extract.

\section{Antibacterial activity}

The Escherichia coli IFO 3301 or Staphylococcus aureus IFO 13276 bacterial strain was used. The bacterial strains were kept as stock cultures maintained in nutrient broth (NB, Franklin Lakes, NJ USA) medium supplemented with $50 \%(\mathrm{v} / \mathrm{v})$ glycerine and incubated at $-80{ }^{\circ} \mathrm{C}$. The stock bacteria were then incubated in nutrient agar (NA, Franklin Lakes, NJ USA) medium at $37^{\circ} \mathrm{C}$ for $24 \mathrm{~h}$. A single colony obtained from pre-culture of $20 \mathrm{ml}$ of NB medium was incubated at $37{ }^{\circ} \mathrm{C}$ and $160 \mathrm{rpm}$ for $8 \mathrm{~h}$. This antibacterial assay was 
performed as previously described by Ravikanth et al. ${ }^{13}$ with slight modifications. Eighty $\mu 1$ of NB medium and $10 \mu 1$ of $20 \%$ DMSO were added with or without (control) to the test samples at various concentrations into 96 well plastic cell culture plates. Pre-cultured bacteria in NB medium $(10 \mu \mathrm{l})$ at a density of $1.0 \times 10^{5} \mathrm{CFU} / \mathrm{ml}($ E. coli $)$ or $1 \times 10^{6} \mathrm{CFU} / \mathrm{ml}$ (S. aureus) were then added into each well, and incubated for $10 \mathrm{~h}$ or $12 \mathrm{~h}$, respectively. The absorbance was measured at $630 \mathrm{~nm}$.

\section{Antihyaluronidase activity}

Antihyaluronidase activity was measured by using the previously described method. ${ }^{14}$ Test samples were dissolved in DMSO, and each solution was diluted with $0.1 \mathrm{M}$ acetate buffer $(\mathrm{pH} 4.0)$ to ten volumes. Hyaluronidase, hyaluronic acid potassium salt and compound 48/80 were dissolved with the same buffer. A mixture of sample solution $(0.20$ $\mathrm{ml})$ and 2000 units $/ \mathrm{ml}$ of hyaluronidase solution $(0.10 \mathrm{ml})$ were pre-incubated at $37^{\circ} \mathrm{C}$ for $20 \mathrm{~min}$. Then $0.10 \mathrm{mg} / \mathrm{ml}$ of compound $48 / 80$ solution $(0.20 \mathrm{ml})$ was added and each mixture was incubated at $37^{\circ} \mathrm{C}$ for $20 \mathrm{~min}$. After incubation, the assay was commenced by adding $0.8 \mathrm{mg} / \mathrm{ml}$ of hyaluronic acid potassium salt solution $(0.50 \mathrm{ml})$ to each tube and incubating at $37^{\circ} \mathrm{C}$ for $40 \mathrm{~min}$. Reactions were terminated by the addition of $0.4 \mathrm{~N} \mathrm{NaOH}$ solution. The absorbance was measured at $585 \mathrm{~nm}$. Cromolyn interrupts the physiological response to nasal antigens and, when used prophylactically, can prevent the onset of symptoms as well as treat nasal allergy symptoms once they occur. In addition to its effects on mast cells, cromolyn inhibits macrophages, eosinophils, monocytes, and platelets believed to play a role in the inflammatory response. ${ }^{15}$ Thus, cromolyn (Sigma Aldrich, USA) was used as a positive control.

\section{Results and discussion}

In the present study, a methanol extract and hot water extract of $P$. citrinopileatus and each soluble prepared from the methanol extract were examined for biological activities at various concentrations. Several bioassays such as melanin inhibition (Table 1), tyrosinase inhibition (Table 2), antioxidants (Table 3), antibacterial (Table 4), and antihyaluronidase activities (Table 5) were conducted.

\section{Melanin inhibition activity}

After treatment of B16 melanoma cells with various samples for 3 days, the cells were 
harvested and two different parameters of cellular function were measured by bioassay, the effects on cell viability (CV) and on melanin content (MC). An important concept when selecting bioactive extracts that modulate skin pigmentation is that, for obvious reasons, they should have minimal effects on cell proliferation and/or survival. In these experiments, the effects on cell proliferation were assessed using the MTT assay, and the effects on melanin content were measured by absorbance at $405 \mathrm{~nm}$ (Table 1).

Samples which showed a percentage of melanin content equal to or lower than $10 \%$ of cell viability (e.g. CV-MC $\geqq 10$ ) were judged as possible active ingredients, and classified as type A. As shown in Table 1, $n$-hexane soluble, diethyl ether soluble, and ethyl acetate soluble were considered as possible candidates based on their effects on B16 melanoma cells. More specifically, the $n$-hexane soluble $(50 \mu \mathrm{g} / \mathrm{ml})$, diethyl ether soluble $(75 \mu \mathrm{g} / \mathrm{ml})$ and ethyl acetate soluble $(100 \mu \mathrm{g} / \mathrm{ml})$ inhibited the melanin production of B16 melanoma cells at $63.1,64.0$, and $58.8 \%$, with cell viability at $61.3,65.8$, and $70.7 \%$, respectively.

This study also found that some extracts showed higher cytotoxicity of more than $75 \%$ versus the control at a concentration of $100 \mu \mathrm{g} / \mathrm{ml}$ (e.g. $n$-hexane soluble), which prohibited us from evaluating their effects on the melanin biosynthesis of B16 melanoma cells. Therefore, extracts that inhibited the growth of B16 melanoma cells more than $75 \%$ versus the control were classified as type C. However, the $n$-hexane soluble which showed potent cytotoxicity at $100 \mu \mathrm{g} / \mathrm{ml}$ surpassed our established standard (type A: CV-MC $\geqq 10$ ) at 75 $\mu \mathrm{g} / \mathrm{ml}$, and $50 \mu \mathrm{g} / \mathrm{ml}$.

\section{Tyrosinase inhibition activity}

Tyrosinase (EC 1.14.18.1) is a key enzyme in melanin synthesis. We investigated the effects of each soluble and the extracts of $P$. citrinopileatus on tyrosinase activity. Table 2 showed that all extracts and solubles exhibited poor tyrosinase inhibitory activity compared with kojic acid (a positive control) for substrates (L-DOPA and L-tyrosine) at a concentration of $100 \mu \mathrm{g} / \mathrm{ml}$. he $n$-hexane soluble and $n$-butanol soluble with L-DOPA as a substrate both showed tyrosinase inhibition at $10.5 \%$ and $10.3 \%$, respectively. Kojic acid used as a positive control showed $100.0 \%$ inhibition at $100 \mu \mathrm{g} / \mathrm{ml}$. In addition, at 100 $\mu \mathrm{g} / \mathrm{ml}$ of samples with L-tyrosine as substrate, the $n$-hexane soluble, diethyl ether soluble, and $n$-butanol soluble showed $28.8,27.4$, and $41.0 \%$ inhibitory activity, respectively. Kojic acid used as a positive control showed $98.6 \%$ inhibition at $100 \mu \mathrm{g} / \mathrm{ml}$.

Based on these results, none of the extracts and solubles prepared from $P$. 
citrinopileatus inhibited more than $50 \%$ of tyrosinase activity up to the concentration of $100 \mu \mathrm{g} / \mathrm{ml}$.

Kojic acid is known as a tyrosinase inhibitor and is used as a skin-whitening cosmetic. Hydroquinone-related compounds have also been used as effective depigmenting agents for skin over pigmentation, but they are strong irritants and exhibit cell toxicity. ${ }^{16}$ It has been reported that some growth factors or cytokines such as basic fibroblast growth factor (bFGF), endotheln-1 (ET-1) and $\alpha$-melanocyte stimulating hormone $(\alpha-\mathrm{MSH})^{17}$ are secreted from ultraviolet (UV)-irradiated keratinocytes or melanocytes and stimulate the proliferation or melanogenesis of human melanocytes.

Considering this information, the results shown in Tables 1 and 2 indicated that the inhibitory effects of $n$-hexane, diethyl ether and ethyl acetate solubles were not caused by the inhibition of tyrosinase activity. The depigmenting mechanism of these extracts involved the suppression of some pigmenting signals in stimulating melanogenesis rather than the direct inhibition of tyrosinase activity.

\section{Antioxidant activity}

Skin is a major candidate target of oxidative stress caused by reactive species (RS), including reactive oxygen species and reactive nitrogen species. RS are major and significant contributors to skin hyperpigmentation and skin aging. It has generally been believed that agents having antioxidant activity show anti-aging, whitening, and anti-inflammatory activities. ${ }^{18}$ If free radicals are inappropriately processed in melanin synthesis, hydrogen peroxide $\left(\mathrm{H}_{2} \mathrm{O}_{2}\right)$ is generated, leading to the production of hydroxyl radicals $(\mathrm{HO} \cdot)$ and other reactive oxygen species (ROS). ${ }^{19}$ Oxidative stress may be induced by increasing the generation of ROS and other free radicals. UV radiation can induce the formation of ROS in skin such as singlet oxygen and superoxide anion, promoting biological damage in exposed tissues via iron-catalyzed oxidative reactions. These ROS enhance melanin biosynthesis, damage DNA, and may induce proliferation of melanocytes. ${ }^{20}$ Yamakoshi et al. ${ }^{20}$ found evidence for a role of oxidative stress in the pathogenesis of skin disorders. It is known that ROS scavengers or inhibitors such as antioxidants may reduce hyperpigmentation. Additionally, superoxide dismutase (SOD, EC 1.15.1.1), which catalyzes the dismutase of the superoxide anion into hydrogen peroxide and molecular oxygen, is one of the most important antioxidative enzymes.

Table 3 shows that the $n$-hexane soluble and diethyl ether soluble of the oxygen radical 
absorbance capacity (ORAC) were 0.25 and $0.20 \mathrm{mg} \mathrm{TE} / \mathrm{mg}$, respectively. However, the ethyl acetate soluble, $n$-butanol soluble, aqueous soluble, methanol extract, and hot water extract showed a lower oxygen radical absorbance capacity at $0.08,0.13,0.04,0.08$, and $0.05 \mathrm{mg} \mathrm{TE} / \mathrm{mg}$, respectively.

DPPH is a stable radical that is used in a popular method of screening for free-radical-scavenging ability. Table 3 shows the DPPH radical scavenging activity of the samples. Several extracts, such as the $n$-butanol soluble, aqueous soluble, methanol extract, and hot water extract showed moderate DPPH radical scavenging activity. These extracts caused $50 \%$ scavenging $\left(\mathrm{IC}_{50}\right)$ of the DPPH radical scavenging activity at concentrations of $7.9,5.2,5.4$, and $4.2 \mathrm{mg} / \mathrm{ml}$, respectively.

The aqueous soluble, methanol extract and hot water extract exhibited 1.9, 0.3, and 2.7 of SOD equivalent activity (U/mg), respectively.

\section{Antibacterial activity}

The general category of cosmetic skin care products includes sunscreens to protect the skin from UV damage, antioxidant products to repair or hide skin imperfections (e.g. wrinkles, dark circles), and antibacterial products to treat acne. Well-known S. aureus and E. coli are widespread, potentially pathogenic type bacteria which cause some skin conditions such as acne, comedo, papules, pustules, and cellulitis. Therefore we evaluated the antibacterial activity of the extracts and soluble prepared from P. citrinopileatus against $S$. aureus and E. coli. Table 4 shows that the $n$-hexane soluble $(0.5 \mathrm{mg} / \mathrm{ml})$ and ethyl acetate soluble $(0.3 \mathrm{mg} / \mathrm{ml})$ showed high antibacterial activity with growth inhibition of 79.6 and $75.6 \%$ against $S$. aureus, and 87.0 and $60.0 \%$ against $E$. coli, respectively.

Mushrooms are rich sources of natural antibiotics; in mushrooms, cell wall polysaccharides such as glucans are well known for their immunomodulatory properties, and many of the externalized secondary metabolites (extracellular secretions by the mycelium) combat bacteria and viruses. ${ }^{23}$ Several compounds such as lentinic acid and lenthionine extracted from Lentinula edodes (Shiitake in Japanese, Xiang gu in Chinese) revealed antifungal and antibacterial activity against S. aureus, Bacillus subtilis and E. coli. Several studies have reported on the antimicrobial activity of other edible mushrooms and their bioactive compounds. Laetiporus sulphureus antioxidant and antimicrobial activities

of the extract of Laetiporus sulphureus were reported and correlated to its phenols and flavonoids contents, and guaiane sesquiterpenoids isolated from the fruit bodies of edible 
Lactarius species proved to have antibacterial activity ${ }^{24}$. In addition, it has already been reported that methyl alcohol extracts of Pleurotus eryngii var. eryngii, P. eryngii var. ferulae, P. ostreatus, P. sajor-caju, Terfezia boudieri and Agaricus bisporus were shown to inhibit to different degrees the growth of Bacillus megaterium, S. aureus, E. coli, Klebsiella pneumoniae, Candida albicans, C. glabrata, Trichophyton spp. and Epidermophyton spp. ${ }^{25}$ However, study of the antibacterial activity of $P$. citrinopileatus has not been reported. Our results indicated the hydrophobic components in $n$-hexane and ethyl acetate soluble from $P$. citrinopileatus have the potential to be an antimicrobial ingredient.

\section{Antihyaluronidase activity}

Hyaluronidase (EC 3.2.1.35) is an endoglycosidase which randomly cleaves internal $\beta$ - $N$-acetyl-hexosamine glucosidic linkages in hyaluronic acid (HA). ${ }^{26}$ Furthermore, hyaluronidase is an enzyme that degrades hyaluronic acid. Mucopolysaccharides are related to histamine release from mast cells in inflammatory reactions. The enzyme has been distributed in a wide range of mammalian tissues, such as synovial fluid, serum, alveolar macrophages, brain, skin, kidney, liver, spleen, and lung. Since hyaluronidase is related to histamine release from mast cells, the inhibitory effect of this enzyme is one of the indexes of the anti-type I allergy. ${ }^{27}$

Table 5 shows the $n$-butanol soluble, aqueous soluble, and methanol extract from $P$. citrinopileatus showed antihyaluronidase activity of $9.7,10.8$ and $25.4 \%$, at the concentration of $2.0,1.1$ and $4.1 \mathrm{mg} / \mathrm{ml}$, respectively.

\section{Conclusion}

In this study, melanin inhibition, tyrosinase inhibition, antioxidant activities, and antibacterial and antihyaluronidase activities of methanol and hot water extracts of the fruiting bodies of $P$. citrinopileatus, and each soluble prepared from the methanol extract, were evaluated. We found that some solubles, for example $n$-hexane $(50 \mu \mathrm{g} / \mathrm{ml})$, diethyl ether $(75 \mu \mathrm{g} / \mathrm{ml})$ and ethyl acetate soluble $(100 \mu \mathrm{g} / \mathrm{ml})$ inhibited the melanin production in B16 melanoma cells at $63.1,64.0$, and $58.8 \%$, with cell viability at $61.3,65.8$, and $70.7 \%$, respectively. The ORAC value of $n$-hexane and diethyl ether soluble were 0.25 and $0.2 \mathrm{mg}$ $\mathrm{TE} / \mathrm{mg}$. On the other hand, the $n$-butanol soluble, aqueous soluble, methanol extract, and hot water extract exhibited moderate antioxidant potential; their inhibitory concentration $\left(\mathrm{IC}_{50}\right)$ that caused $50 \%$ scavenging of the DPPH radical scavenging were 7.9, 5.2, 5.4 and 
$4.2 \mathrm{mg} / \mathrm{ml}$, respectively. The aqueous soluble, methanol extract, and hot water extract exhibited 1.9, 0.3 and 2.7 of SOD-like activity $(\mathrm{U} / \mathrm{mg})$, respectively. The $n$-hexane soluble $(0.5 \mathrm{mg} / \mathrm{ml})$ and ethyl acetate soluble $(0.3 \mathrm{mg} / \mathrm{ml})$ showed potential antibacterial activity. The $n$-butanol soluble $(2.0 \mathrm{mg} / \mathrm{ml})$, aqueous soluble $(1.1 \mathrm{mg} / \mathrm{ml})$, and methanol extract $(4.1$ $\mathrm{mg} / \mathrm{ml}$ ) showed antihyaluronidase activity of $9.7,10.8$ and $25.4 \%$ respectively. As a result, the fruiting bodies of $P$. citrinopileatus have potential to be an ingredient in skin cosmetics because of their antimelanogenesis, antioxidant, antimicrobial and antihyaluronidase activities. Currently, isolation and identification of the biologically active components from the extracts of $P$. citrinopileatus is in progress.

\section{Acknowledgment}

We are very grateful for Mr. Eiji Nagasawa, Dr. Hiroto Suhara, Dr. Tolgor Bau and Mr. Shuhei Kaneko for valuable comments on scientific name of $P$. citrinopileatus. 


\section{References}

1. Khlood MEB, Laila S, Kaampwe M, Zein S, Mohamed S, Mayumi I, Akio K, Shoichi F (2005) Antigenotoxic effect of Pleurotus cornucopiae extracts on the mutagenesis of salmonella typhimurium TA 98 elicited by benzo [a] pyrene and oxidative DNA lesions in V79 hamster lung cells. Japanese journal of veterinary research, 52, 163-172

2. Janga JH, Jeonga SC, Kimb JH, Leeb YH, Jub YC, Leea JS (2011) Characterization of a new antihypertensive angiotensin I-converting enzyme inhibitory peptide from Pleurotus cornucopiae. Food Chemistry, In Press, Accepted Manuscript

3. Shu HH, Zeng CL, Yi CC (2006) Antihyperlipidemic and antioxidant effects of extracts from Pleurotus citrinopileatus. Journal of agricultural and food chemistry, 54, 2103-2110

4. Tomiyama T, Kaihou S, Ishida M, Nishikawa H, Yamazaki N, Tsuji K, Mitsutake S, Igarashi Y (2008) The water retention effects and action for atopic dermatitis-like symptoms of ethyl alcohol extract (from tamogi-take mushroom) on animal model of atopic dermatitis. Journal of Japanese Society of Nutrition and Food Science, 61, 21-26

5. Kim JH, Kim SJ, Park HR, Choi JI, Ju YC, Nam KC, Kim SJ, Lee SC (2009) The different antioxidant and anticancer activities depending on the color of oyster mushrooms. Journal of Medicinal Plants Research, 3, 1016-1020

6. Wong JH, Ng TB, Jiang Y, Liu F, Sze SC, Zhang KY (2010) Purification and characterization of a laccase with inhibitory activity toward HIV-1 reverse transcriptase and tumor cells from an Edible Mushroom (Pleurotus cornucopiae). Protein and Peptide Letters, 17, 1040-1047

7. Takakura Y, Oka N, Kajiwara H, Tsunashima M, Usami S, Tsukamoto H, Ishida Y, Yamamoto $\mathrm{T}$ (2010) Tamavidin, a versatile affinity tag for protein purification and immobilization. Journal of Biotechnology, 145, 317-322

8. Arung ET, Shimizu K, Kondo R (2006) Inhibitory effect of artocarpanone from Artocarpus heterophyllus on melanin biosynthesis. Biological Pharmaceutical Bulletin, 29, 1966-1969.

9. Cabanes J, Chazarra S, Garcia-Carmona F (1994) Kojic acid, a cosmetic skin whitening agent, is a slow-binding inhibitor of catecholase activity of tyrosinase. The Journal of Pharmacy and Pharmacology, 46, 982-985

10. Prior RL, Hoang H, Gu L, Wu X, Bacchioca M, Howard L (2003) Assays for 
hydrophilic and lipophilic antioxidant capacity (oxygen radical absorbance capacity of plasma and other biological and food samples. Journal of Agricultural and Food Chemistry, 51, 3273-3279

11. Shimamura T, Matsuura R, Tokuda T, Sugimoto N, Yamasaki T, Matsufuji H, Matsui T, Matsumoto K, Ukeda H (2007) Comparison of conventional antioxidant assays for evaluating potencies of natural antioxidants as food additives by collaborative study. Nippon Shokuhin Kagaku Kaishi, 54, 482-487

12. Nakamura K, Ogasawara Y, Endou K, Fujimori S, Koyama M, Akano H (2010) Phenolic compounds responsible for the superoxide dismutase-like activity in high-Brix apple vinegar. Journal of agricultural and food chemistry, 58, 10124-10132

13. Ravikanth V, Tiffany LW, Harsh PB, Frank RS, Jorge MV (2004) Phytotoxic and antimicrobial activities of catechin derivatives. Journal of Agricultural and Food Chemistry, 52, 1077-1082

14. Ono M, Masuoka C, Ito Y, Niiho Y, Kinjo J, Nohara T (1997) Antioxidative and antihyaluronidase activities of some constituents from foeniculi fructus (fruit of Foeniculum vulgare Miller). Food Science and Technology International, Tokyo, 3, 53-55

15. Holgate ST (1989) Reflections on the mechanism(s) of action of sodium cromoglycate (Intal) and the role of mast cells in asthma. Respiratory Medicine, 83 (suppl A), 25-31

16. Curto EV, Kwong C, Hermersdörfer H, Glatt H, Santis C, Virador V, Hearing VJ Jr, Dooley TP (1999) Inhibitors of mammalian melanocyte tyrosinase: in vitro comparisons of alkyl esters of gentisic acid with other putative inhibitors. Biochemical Pharmacology, 57, 663-672

17. Thody AJ (1999) Alpha-MSH and the regulation of melanocyte function. Annals of the New York Academy of Sciences, 885, 217-229

18. Choi MY, Song HS, Hur HS, Sim SS (2008) Whitening activity of luteolin related to the inhibition of cAMP pathway in alpha-MSH-stimulated B16 melanoma cells. Archives of Pharmacal Research, 31, 1166-1171

19. Perluigi M, De-Marco F, Foppoli C, Coccia R, Blarzino C, Marcante ML, Cini C (2003) Tyrosinase protects human melanocytes from ROS-generating compounds. Biochem Biophys Res Commun, 305, 250-256

20. Yamakoshi J, Otsuka F, Sano A, Tokutake S, Saito M, Kikuchi M, Kubota Y (2003) Lightening effect on ultraviolet-induced pigmentation of guinea pig skin by oral 
administration of a proanthocyanidin-rich extract from grape seeds. Pigment cell research, 16, 629-638

21. Bao HND, Shio UH, Ohshima T (2009) Antioxidative activities of mushroom (Flammulina velutipes) extract added to bigeye tuna meat: Dose-dependent efficacy and comparison with other biological Antioxidants. Journal of Food Science,74 (2), C162-169

22. Bao HND, Osako K, Ohshima T (2010) Value-added use of mushroom ergothioneine as a colour stabilizer in processed fish meats. Journal of the Science of Food and Agriculture, 90 (10), 1634-1641

23. Brandt CR, Piraino F (2000) Musrhoom antivirals. Recent Research Developments for Antimicrobial Agents and Chemotherapy, 4, 11-26

24. Anke H, Bergendorff O, Sterner O (1989) Assays of the biological activities of guaiane sesquiterpenoids isolated from the fruit bodies of edible Lactarius species. Food and Chemical Toxicology, 27, 393-397

25. Mehmet A, Ayse-Nilay O, Pınar E, Sevda K (2010) Antimicrobial activity of some edible mushrooms in the eastern and southeast anatolia region of turkey. Gazi University Journal of Science, 23, 125-130

26. Kulyk WM, Kosher RA (1987) Temporal and spatial analysis of hyaluronidase activity during development of the embryonic chick limb bud. Developmental Biology, 120, $535-541$

27. Kakegawa H, Matsumoto H, Satoh T (1985) Activation of hyaluronidase by metallic salts and compound 48/80, and inhibitory effect of anti-allergic agents on Hyaluronidase. Chemical Pharmaceutical Bulletin, 33, 642-646 
Table 1. Effects of methanol extract and each soluble prepared from the methanol extract, and hot water extract of $P$. citrinopileatus on melanin biosynthesis and cell proliferation of B16 melanoma cells

\begin{tabular}{|c|c|c|c|c|c|c|c|c|c|c|c|c|}
\hline \multirow{2}{*}{ Samples tested } & \multicolumn{3}{|c|}{$100 \mu \mathrm{g} / \mathrm{ml}$} & \multicolumn{3}{|c|}{$75 \mu \mathrm{g} / \mathrm{ml}$} & \multicolumn{3}{|c|}{$50 \mu \mathrm{g} / \mathrm{ml}$} & \multicolumn{3}{|c|}{$25 \mu \mathrm{g} / \mathrm{ml}$} \\
\hline & $\mathrm{MC}$ & $\mathrm{CV}$ & Type $^{a}$ & $\mathrm{MC}$ & $\mathrm{CV}$ & Type & $\mathrm{MC}$ & $\mathrm{CV}$ & Type & $\mathrm{MC}$ & $\mathrm{CV}$ & Type \\
\hline Methanol extract & $96.1 \pm 0.97$ & $87.1 \pm 3.95$ & $B$ & $94.5 \pm 3.67$ & $95.9 \pm 1.57$ & $B$ & $98.5 \pm 9.9$ & $93.2 \pm 0.49$ & $\mathrm{~B}$ & $102.8 \pm 4.03$ & $97.1 \pm 0.96$ & B \\
\hline$n$-Hexane soluble & $16.9 \pm 1.75$ & $20.1 \pm 2.02$ & C & $20.5 \pm 1.66$ & $31.5 \pm 7.69$ & A & $36.9 \pm 6.89$ & $61.3 \pm 5.73$ & A & $75.5 \pm 7.16$ & $85.3 \pm 5.96$ & B \\
\hline Diethyl ether soluble & $27.7 \pm 3.43$ & $53.6 \pm 8.42$ & . $A$ & $36.0 \pm 1.56$ & $65.8 \pm 2.48$ & A & $54.6 \pm 6.20$ & $65.7 \pm 2.40$ & A & $84.5 \pm 4.9$ & $95.8 \pm 2.69$ & $A$ \\
\hline Ethyl acetate soluble & $41.2 \pm 1.42$ & $70.7 \pm 4.28$ & $A$ & $47.3 \pm 2.55$ & $75.4 \pm 0.87$ & A & $53.8 \pm 2.42$ & $76.8 \pm 8.61$ & A & $90.2 \pm 0.84$ & $97.9 \pm 4.04$ & $\mathrm{~B}$ \\
\hline$n$-Butanol soluble & $116.6 \pm 2.23$ & $99.7 \pm 2.04$ & B & $121.2 \pm 4.21$ & $101.2 \pm 0.27$ & B & $116.1 \pm 1.23$ & $100.5 \pm 1.85$ & B & $118.8 \pm 4.12$ & $103.4 \pm 0.89$ & B \\
\hline Aqueous soluble & $99.8 \pm 3.12$ & $98.4 \pm 1.59$ & $B$ & $103.5 \pm 4.91$ & $96.1 \pm 0.47$ & $\mathrm{~B}$ & $97.1 \pm 3.69$ & $98.2 \pm 1.27$ & B & $103.6 \pm 1.42$ & $98.3 \pm 1.62$ & B \\
\hline Hot water extract & $116.3 \pm 3.31$ & $96.1 \pm 3.62$ & B & $104.5 \pm 4.11$ & $91.8 \pm 6.04$ & B & $16.7 \pm 11.24$ & $90.7 \pm 1.93$ & B & $106.5 \pm 9.73$ & $87.1 \pm 4.73$ & B \\
\hline Arbutin (Positive control) & $40.7 \pm 1.45$ & $98.4 \pm 3.85$ & $\mathrm{~A}$ & $43.2 \pm 2.76$ & $86.4 \pm 0.76$ & A & $45.8 \pm 2.46$ & $85.2 \pm 3.12$ & A & $53.6 \pm 0.77$ & $84.7 \pm 3.32$ & A \\
\hline
\end{tabular}

MC, melanin content (\%); CV, cell viability (\%); a Type A: CV-MC $\geqq 10 \%$; type B: MC \& CV $\geqq 75 \%$; type C: MC \& CV $\leqq 25 \%$. Data presented as means \pm SD $(n=3)$. 
Table 2. The effect of methanol extract and each soluble prepared from the methanol extract, and hot water extract of $P$. citrinopileatus on tyrosinase

\begin{tabular}{lrc}
\hline \multirow{2}{*}{ Samples * } & \multicolumn{2}{c}{ Tyrosinase inhibition (\% vs. control) } \\
\cline { 2 - 3 } & \multicolumn{1}{c}{ L-DOPA $^{* *}$} & \multicolumn{1}{c}{ L-Tyrosine ${ }^{* *}$} \\
\hline Methanol extract & $2.8 \pm 2.44$ & $3.0 \pm 2.78$ \\
$n$-Hexane soluble & $10.5 \pm 3.51$ & $28.8 \pm 1.22$ \\
Diethyl ether soluble & $8.3 \pm 2.36$ & $2.1 \pm 1.82$ \\
Ethyl acetate soluble & $8.3 \pm 2.36$ & $27.4 \pm 2.47$ \\
$n$-Butanol soluble & $10.3 \pm 3.42$ & $41.0 \pm 1.35$ \\
Aqueous soluble & $2.5 \pm 3.95$ & $9.1 \pm 4.16$ \\
Hot water extract & $6.5 \pm 1.32$ & $2.3 \pm 2.15$ \\
Kojic acid (Positive control) & $100.0 \pm 0.06$ & $98.6 \pm 0.61$ \\
\hline
\end{tabular}

*Sample concentration is $100 \mu \mathrm{g} / \mathrm{ml}$; Data presented as means \pm SD $(\mathrm{n}=3)$.

** Substrate 
Table 3. Antioxidant activity of the methanol extract, each soluble prepared from the methanol extract, and the hot water extract of $P$. citrinopileatus

\begin{tabular}{lccc}
\hline \multirow{2}{*}{ Sample } & \multicolumn{3}{c}{ Antioxidant assay } \\
\cline { 2 - 4 } & ORAC $(\mathrm{mg} \mathrm{TE} / \mathrm{mg})^{\star}$ & $\mathrm{DPPH}\left[\mathrm{IC} \mathrm{C}_{50}(\mathrm{mg} / \mathrm{ml})\right]$ & SOD-like activity $(\mathrm{U} / \mathrm{mg})$ \\
\hline Methanol extract & $0.08 \pm 0.007$ & 5.4 & $0.3 \pm 0.05$ \\
$n$-Hexane soluble & $0.25 \pm 0.009$ & $>4.0^{\mathrm{a}}$ & $0.01^{\mathrm{b}}$ \\
Diethyl ether soluble & $0.20 \pm 0.008$ & $>4.0^{\mathrm{a}}$ & $0.01^{\mathrm{b}}$ \\
Ethyl acetate soluble & $0.08 \pm 0.002$ & $>1.7^{\mathrm{a}}$ & $0.01^{\mathrm{b}}$ \\
$n$-Butanol soluble & $0.13 \pm 0.006$ & 7.9 & $\mathrm{nd}$ \\
Aqueous soluble & $0.04 \pm 0.004$ & 5.2 & $1.9 \pm 0.63$ \\
Hot water extract & $0.05 \pm 0.003$ & 4.2 & $2.7 \pm 0.59$ \\
\hline
\end{tabular}

* ORAC values are expressed as relative Trolox equivalent per microgram. ${ }^{a}$ no activity up to each concentration, but not tested at higher concentration because of limited solubility. ${ }^{b}$ hardly any activity. ${ }^{\text {nd }}$ not determined because of below mesurable limit. Data presented as means $\pm S D$ $(n=3)$ 
Table 4. Antibacterial activity of methanol extrat, each soluble prepared form methanol extract and hot water extract of $P$. citrinopileatus

\begin{tabular}{lccc}
\hline \multirow{2}{*}{ Samples tested } & $\begin{array}{c}\text { Concentration } \\
(\mathrm{mg} / \mathrm{ml})\end{array}$ & \multicolumn{2}{c}{ Growth inhibition $(\%$ vs. control) } \\
\cline { 3 - 4 } & 2.0 & S. aureus & E. coli \\
\hline Methanol extract & 0.5 & $79.6 \pm 1.81$ & - \\
$n$-Hexane soluble & 1.0 & $35.5 \pm 7.18$ & $25.7 \pm 7.72$ \\
Diethyl ether soluble & 0.3 & $75.6 \pm 3.79$ & $60.0 \pm 7.43$ \\
Ethyl acetate soluble & 0.5 & - & - \\
$n$-Butanol soluble & 1.0 & - & $26.4 \pm 7.85$ \\
Aqueous soluble & 2.0 & - & - \\
Hot water extract & 0.2 & $100 \pm 0.68$ & $100 \pm 4.12$ \\
Sorbic acid (Positive control) & 0.2 &
\end{tabular}

- No antibacterial activity; Data presented as means $\pm S D(n=3)$. 
Table 5. The effect of methanol extract, each soluble prepared form the methanol extract, and hot water extract of $P$. citrinopileatus on hyaluronidase

\begin{tabular}{lcc}
\hline Samples tested & $\begin{array}{c}\text { Concentration } \\
(\mathrm{mg} / \mathrm{ml})\end{array}$ & $\begin{array}{c}\text { Hyaluronidase inhibition } \\
(\% \text { vs control })\end{array}$ \\
\hline Methanol extract & 4.1 & $25.4 \pm 2.1$ \\
$n$-Hexane soluble & 3.7 & - \\
Diethyl ether soluble & 2.7 & - \\
Ethyl acetate soluble & 2.5 & - \\
$n$-Butanol soluble & 2.0 & $9.7 \pm 2.1$ \\
Aqueous soluble & 1.1 & $10.8 \pm 1.7$ \\
Hot water extract & 2.1 & - \\
Cromolyn sodium salt (Positive control) & 1.0 & $84.8 \pm 1.0$ \\
\hline,- Not hyaluronidase inhibition; Data presented as means $\pm \mathrm{SD}(\mathrm{n}=3)$.
\end{tabular}

